\title{
Is a posthumanist Bildung possible? Reclaiming the promise of Bildung for contemporary higher education
}

\author{
Carol A. Taylor ${ }^{1}$
}

Published online: 23 March 2016

(C) The Author(s) 2016. This article is published with open access at Springerlink.com

\begin{abstract}
My central argument in this article is that the notion of Bildung may offer conceptual sustenance to those who wish to develop educative practices to supplement or contest the prevalence and privileging of market and economic imperatives in higher education, which configure teaching and learning as an object available to measurement. I pursue this argument by making the case for an ethical posthuman Bildung which recognises the inseparability of knowing and being, the materiality of educative relations, and the need to install an ecology of ethical relations at the centre of educational practice in higher education. Such a re-conceptualisation situates Bildung not purely as an individual goal but as a process of ecologies and relationships. The article explores Bildung as a flexible concept, via three theoretical lenses, and notes that it has always been subject to continuing revision in response to changing social and educational contexts. In proposing the possibility of, and need for, a posthuman Bildung, the articles offer a critical review of the promise of Bildung and outline some of the radical ways that a posthuman Bildung might reinvigorate conceptualisations of contemporary higher education.
\end{abstract}

Keywords Bildung $\cdot$ Posthumanism $\cdot$ Higher education $\cdot$ Ethics $\cdot$ Ecology

\section{Introduction}

I use this article to do some wondering without confirmation about Bildung. The question that drives this article is: is a posthumanist Bildung possible? This question arises from my current research which is on posthumanist approaches to educational research and which focuses on the agency of things, materialities and spaces, the force these more-than-human agencies have, and the way they act relationally with humans in educational processes.

Carol A. Taylor

C.A.Taylor@shu.ac.uk

1 Sheffield Institute of Education, Sheffield Hallam University, Arundel Building Room 10106, 122

Charles Street, Sheffield S1 2NE, UK 
Such a posthuman stance necessarily involves the decentring of the human-which piques my curiosity about whether, how, or if, a posthumanist stance on educative practices might speak to the concept of Bildung in any meaningful way. At the very least, such a wondering without confirmation will bring something of the rich tradition of European thought about Bildung into contact with some problems in innovative methodologies for investigating higher education at the current time.

I begin by locating my argument in relation to higher education and the ontological turn. For those in the Anglophone tradition who may be unfamiliar with the concept of Bildung, I then explain its main features. After this, I consider a number of theoretical points of departure which have reshaped Bildung through a variety of lenses, notably critical theory, postmodernist and canine Bildung. These contemporary theorisations posit Bildung as a mobile concept, and give me reason to think it is worth exploring the question: is a posthumanist Bildung possible?

\section{The changing higher education landscape, the ontological turn and Bildung}

Recent years have witnessed concerted policy moves to reconfigure higher education in the UK along neoliberal market lines. The contours of current discourses about marketisation in higher education are well known and are detailed in a now rather substantial body of the literature tracing how economic instrumentalism and measurement imperatives are conditioning teaching, learning and the student experience in higher education (Molesworth et al. 2011; Ransome 2011; Taylor and McCaig 2014). At the centre of these discourses is the argument that increases in student fees and imperatives to increase student choice have led to the rise of the student as sovereign consumer. Two significant effects have followed from this. One, that there has been a shift in the nature of teaching and learning, from a relation based on academic scholarship to a relation in which lecturers are 'service providers', students are 'consumers', and the value of learning is subject to level of 'satisfaction'. The second effect concerns the increased competition between universities, exemplified by the intensification of institutions' concerns about, and financial investments in, securing their 'place', 'position' and 'brand' in national, international and global league tables. Its critics argue that in this changing higher education landscape of competition and distinction, international and national measures of teaching and research 'quality' loom ever larger, and teaching and learning are becoming increasingly commoditised along input-output lines akin to industrialised processes (Barnes and Jenkins 2014; Ranson 2003; Sayer 2011). Indeed, some might see this as the intention of the recent Green Paper which aims to push forward with the measurement and rating of universities' teaching excellence (BIS 2015). In this context, fears for the loss of criticality that attends deep engagement with processes of learning have been expressed (Barnett 2013), alongside concerns about the diminishment of trust and agency in a higher education sector that is more and more oriented to seeing learning as a privatised means to achieve instrumental ends.

The overall picture, though, is more complex. In particular, there is a body of teaching and learning work in the UK which demonstrates considerable pushback against the hold of marketisation. This work is heterogeneous, draws on a diverse range of philosophical traditions and, in some cases, is articulated to specific political-critical allegiances. It includes, for example, the whole institution configuration of teaching and learning under the banner of 'student-as-researcher' at Lincoln University (Neary 2010; Bovill et al. 2011) 
work on the student-lecturer co-construction of undergraduate curricula; Taylor and McCaig's (2014) evidence regarding lecturers' commitment to collegial, democratic and dialogic modes of teaching and learning, recent movements to embed partnership practices into pedagogy (Healey et al. 2014), and a sustained interest in the development of more nuanced understandings of teaching 'quality' and student 'satisfaction' (Buckley 2014). While all these endeavours illuminate a widespread interest in ways of 'doing' pedagogy that contest the commoditisation and instrumentalism of learning and teaching that marketised assumptions presume, their broader importance is that they provide practical instances of the gathering pace of the 'ontological turn' in higher education.

While the performative exigencies of neoliberalism privilege the acquisition of skills, the linear transmission of knowledge and the measurement of learning, the ontological turn shifts the focus back to a notion of education centred on being and becoming. Emphasising the potentially transformative power of education in the life of the individual opens a way to rethink the 'commitment, openness, wonder [and] passion' of learning (Dall'Alba and Barnacle 2007, p. 681). This is where the European concept of Bildung might be usefully brought in. While there is no easy translation into English of this complex concept, Bildung generally refers to developing, shaping, self-formation and inner cultivation, and speaks to 'the holistic development of the individual, as well as about broader hopes for a better society' (Horlacher 2004, p. 409).

In the Anglophone world, Bildung is perhaps most readily associated with Humboldt's idea of the university as materialised in the founding of the University of Berlin in 1810. This university, as Collini (2012) notes, sets the modern standard for higher learning in its separation from the church, allegiance to individual autonomy, freedom from ideological interference, and the inclusion of research alongside teaching. Bildung was, in Humboldt's conceptualisation, both a political and educational project which enabled the disinterested scholar to pursue a 'universal' education based on the seven liberal arts: the trivium of grammar, logic, rhetoric and the quadrivium of arithmetic, geometry, astronomy, music, in the context of a lifelong project of self-formation which was no less than the individual pursuit of autonomy and self-perfection (Kern 2010). Although since then, Bildung's liberal political origins have been reshaped, it is still a politically oriented concept as later discussions about Bildung and citizenship indicate, and it is, perhaps, Humboldt's political sensibility which most clearly differentiates his idea of the university from Newman's. While both may agree that a university is grounded in a broad education provided by the liberal arts, and that a university education must be clearly differentiated from a vocational education located with the professions, Humboldt's notion of Bildung as an individual's lifelong journey to self-knowledge via their passage within the world is distinctly at odds with Newman's (1996, p. 103) view that 'the scope of a University [is] Knowledge which is its own end'. Furthermore, Collini (2012, pp. 45-51) reminds us that, for Newman, the liberal arts were a mode of 'genteel study' designed to promulgate a set of attributes, qualities and cast of mind, whose end was to train the 'best' members of society in avoiding the evils of 'one-sidedness', and which were only attainable through a 3-year residence at an elite Oxbridge-type institution. However, while Newmam's work has been profoundly influential in the UK, particularly in promoting an idea of the university as a place for broader interdisciplinary learning, his vision is a far cry from the intellectual and ontological travails which Bildung entails for all those who pursue higher learning.

My argument in this article is that the notion of Bildung may offer conceptual sustenance to those who wish to develop educative practices to supplement or contest the privileging of market and economic imperatives in higher education which configure teaching and learning as an object available to measurement via performance indicators 
(HEFCE 2015; HESA 2015). I make the case for a posthuman Bildung which recognises the inseparability of knowing and being, the materiality of educative relations, and the need to install an ecology of ethical relations at the centre of educational practice in higher education. Such a conceptualisation situates Bildung not purely as an individual goal but as a process of ecologies and relationships. Bildung has always been a flexible concept, subject to continuing revision in response to changing social and educational contexts. In proposing the possibility of, and need for, a posthuman Bildung, I critically review the promise of Bildung and outline some of the radical ways that a posthuman Bildung might reinvigorate conceptualisations of contemporary English higher education.

\section{Bildung: 'not a "thing” on its own'}

Before considering the case for a posthuman Bildung, it is necessary first to approach the question 'what is Bildung?' Biesta's (2002a, p. 344) response indicates the wide orbit for this question: it is, he advises, "important to acknowledge that there is no such "thing" as Bildung, that it is not a "thing" on its own'. Dohmen (1964), likewise, concedes that Bildung is one of the most ambiguous and vague but fundamental concepts of German pedagogy, while for Giesinger (2012, p. 13) it is a 'container' word used for various purposes. Nevertheless, Horlacher (2004, p. 409) notes that Bildung is still a popular concept and one which gestures towards 'grandness and splendour' to the extent that it deals with those inner qualities which have been considered to be higher and spiritual. It has been figured as both an intellectual and moral endeavour; it is about more than knowledge, and it is about sensibility and character; and while its focus is the holistic development of the individual, it is also about how individual cultivation is articulated to a vision of a better society. The central concern of Bildung is what constitutes an educated or cultivated human being? the answer to which "is not given in terms of discipline, socialisation or moralisation, i.e., as the adaptation to an existing "external" order. Bildung refers to the cultivation of the inner life, i.e., the human mind or human soul' (Biesta 2002a, p. 345).

Horlacher (2004) explains that, as it developed, Bildung acted as a centripetal force, drawing in concepts of good sense, good taste, virtue and free will as an internalised responsibility for one's own actions. As taken up by Herder and shaped into an influential pedagogic force, Bildung combines knowledge and feelings or sentiments and requires an education imbibing the 'arts and sciences that made us human, that formed and cultivated us as human beings' (Horlacher 2004, p. 423). Bildung as an 'inner sanctum' for the 'enlightened, trained, fine, reasonable, educated [gebildet], virtuous, enjoying human being that God demands' (Herder 1769, cited in Horlacher 2004, p. 420) lent authority to the idea of pedagogy as a discipline in its own right. With this move, Herder frames a conceptualisation of national and German education 'into which theories of the soul are integrated' but-and this is the crucial point-Bildung is not about 'inwardness itself but the integration of inwardness into a national pedagogical scenery' (Oelkers 1999, p. 36) oriented to the development of individual freedom through interaction between self and world.

It will be evident from this that Bildung has deep affinities with Enlightenment goals and principles such as commitment to progress, belief in the technologies of individual self-improvement, and the civilising mission of education as a vehicle for social improvement. As such — and despite claims that its focus on the inner life renders Bildung apolitical (Oelkers 1999)_Bildung is an historically specific construction with 
educational, political and social dimensions (Biesta 2002a). As Biesta (2002a, p. 346) explains, 'the (modern) conception of Bildung was a very specific answer to a very specific question - the question of citizenship in an emerging civil society-and not, therefore, something universal, external or "typically human". This political and educative mission drew its force from conceptualisations of human reason and understanding derived from Kant which posited education as a political project of entry into civil society which was at the same time an educative project of personal emancipation from the bonds of tradition (Biesta 2002a, b).

\section{Bildung: a mobile concept}

It may already be apparent from this that the Enlightenment origins and conceptual development of Bildung in modernity tie it firmly to Western-centric, individualistic and colonialist modes of understanding. What of this inheritance is useful in rethinking Bildung in posthumanist times? In answering this question, I approach Bildung as a mobile concept, building on the different ways in which different theorists have reinterpreted, rearticulated and recast Bildung in order to interrogate its continuing usefulness in explaining educational practices, phenomena and problems. Thus, the approach to Bildung I take is inspired by Deleuze and Guattari who, in What is Philosophy? argue that 'concepts are not waiting for us ready-made, like heavenly bodies ... they must be invented, fabricated, or rather created' (Deleuze and Guattari 1994, p. 5). They go on to say 'there is no heaven for concepts' (1994, p. 5) and that concepts find their value in being put to use. In what follows, I outline three ways in which Bildung has been put to use as a concept. These have not been chosen arbitrarily but with two purposes in mind: one, to illuminate the radical ways that some thinkers have sought to use Bildung as a means to find answers to new theoretical and practical questions about education, and two, to provide a background to, and springboard for, the main question regarding the possibility for a posthuman Bildung with which this article is concerned.

\section{Bildung and critical theory}

In 2002, Gur-Ze'ev considered the extent to which Bildung and the critical theory of the Frankfurt School were compatible in postmodern educational times. His central point is that 'the thinkers of the Frankfurt School conceived their critical project as inseparable from the tradition of Enlightenment and from the mission of Bildung' (Gur-Ze'ev 2002, p. 391). However, Gur-Ze'ev shows that maintaining an allegiance to the mission of Bildung required the Frankfurt School to reshape the concept of Bildung alongside their own transformations of their project of critical theory as that project developed during the course of their intellectual activity. In the first 'utopian' phase of their thinking, Benjamin, Horkheimer, Adorno and Marcuse found Bildung amenable to their thinking because Bildung, as an educative mode, does not reduce education to mere cultivation, normalisation or socialisation, but stresses the importance of self-cultivation related both to inwardness (see above) and to the subject's autonomy. The Frankfurt School thinkers' 'uncompromising commitment to free will or human autonomy as a central human characteristic' (ibid, p. 392) was, at least in this initial phase, entirely consonant with Bildung because of the emphasis on the possibility for transcendence into a more humane way of life. However, in the second phase of the development of critical theory, Adorno and 
Horkheimer abandoned this initial optimism. The second world war, the seeming hegemony of Instrumental Rationality, and the apparent inability of the individual to realise their autonomy, made it seem that the promise of Bildung and of the Enlightenment ideals it encoded were impossible to realise. The philosophical pessimism this resulted in is characteristic of the Frankfurt School's 'mature critical theory' although, as Gur-Ze'ev (2002, p. 395) is at pains to point out, there was no change in their commitment to 'the possibility of critical work and political resistance'.

Rather than abandon Bildung as a lost cause they therefore tried to recast it to suit their pessimistic critical philosophy. The scale of this recasting was, though, enormous, as is indicated by Horkheimer's view that the 'individual is never at one with herself but always an instrument of some other agency, which manipulates her for its own benefit' (Gur-Ze'ev 2002, p. 396). Add to this the general view of the critical theorists that the human alienation produced by modernity made inwardness impossible. In order to hang onto a germ of the emancipatory commitment shared by Bildung and the Enlightenment, the Frankfurt School thinkers articulated Bildung pessimistically in a negative manner. Driven by their exile state, they used pessimism as an impetus to continue with utopian thinking: alienation and suffering became a 'worthy stance' (ibid, p. 400) from which to take an evaluative look at the world. Late Adorno and Horkheimer, therefore, generated a new, negative utopian concept of Bildung which sought to activate social critique as 'a moral-philosophicalexistential-political alternative rather than 'critical thinking' or 'deconstruction' (ibid, p. 404). This revised notion of social critique offered by late critical theory is ground in suffering but aims at hope through the possibilities of a counter-education characterised as self-cultivation, reflection and emancipatory praxis. Crucially, Horkheimer considered that the universities and the process of higher education still offered hope for an articulation of Bildung linked to social, political and critical ends. Late critical theory, therefore, reintroduced Bildung as a 'mission, not as a tool' (ibid, p. 403) but, as Gur-Ze'ev (2002, p. 400) notes, its relevance 'could not have been sustained without a dramatic transformation in its conceptual preconditions, meanings and aims'.

\section{A postmodern, postcolonial Bildung}

Postmodern and postcolonial reconstructions of Bildung throw Enlightenment assumptions about the self into doubt. 'Classical' notions of Bildung presume that the subject is an integrated albeit mutable entity: the person has $a$ self-soul-identity, is composed of a durable inner substance, and that it is possible, though educative practices, both to get to know oneself and one's inner core 'better', and to effect changes to improve oneself through education. Humboldt's university is the raison d'etre for this notion of Bildung. The assumption that personal progress is possible is disputed by postmodernism, as is the assumption of the unitary self with a stable ego. Postmodern understandings figure the self as a multiplicity, as produced in and through fragmentation, as plural and contingent, as a set of locating co-ordinates not a fixed point; and see those engaged in higher education as knowledge wayfarers whose physical and ontological learning journeys are characterised by nomadic, erratic and recursive moves of un-learning, re-finding (out) or undoing of previous ways of knowing, rather than a teleology of self-improvement through educative practices (Stronach and MacLure 1997).

The contingency and social constructedness of the postmodernist self is echoed in postcolonial understandings which pose the self as hybrid, instituted through difference, and the product of multiple power plays. Postcolonial theorists such as Fanon, Said and Anderson have shown how colonialism worked as a system which propped itself up by 
producing 'otherness'. The identities of the colonisers were produced in opposition to those they colonised, and those identities were ontologically justified through the cultural imposition of a range of binaries: civilised/savage; progressive/unenlightened; rational/ emotional; culture/nature; ordered/wild — and secured by sometimes violent repression of local, indigenous epistemologies. Education, as a process of social and cultural formation and improvement, was considered by colonialists to be a civilising mission, and the educators' task was to bring the best that is thought and known in the West to these 'others' whose cultural lack indicated their great need. Hence, postmodernist and postcolonial theorisations critique the assimilationist goals of Western education, in which Bildung figures as a normative technology of the self, infused with colonial, elitist and masculinist assumptions about identity, rationality and the nature of progress. This Bildung is responsible for the epistemological erasure and othering of those forms of knowledge that contest the humanist Enlightenment master narrative of reason, 'truth' and objectivity.

However, some postmodern and postcolonial theorists wish to widen the scope of Bildung and claim some of its ingredients for their educative project. There are three factors which motivate this endeavour. The first is the need for more plural understandings of the 'self'. When the self is foreground as a social practice enmeshed within social contexts and in relation to which individuals form and reform themselves as persons, then it is possible to move away from essentialist notions of self that underpinned 'classical' forms of Bildung. Postmodern and postcolonial notions, then, open towards a form of Bildung which begins to think about identity as process of becoming-other, and in which Bildung may figure as a radical opening up of the self to the other. Gur-Ze'ev (2002), thus, proposes a postmodern Bildung that draws on Levinas to rethink self-cultivation within a dialogical relation with others. Castle (2013) proposes Bildung as a form of ongoing experimentalism to find new ways of self-formation in a global world. Likewise, Thavenius (1995) stresses that Bildung can be configured as a mode of deliberate confrontation with the aesthetics of contemporary media forms out of which identity is constructed, rather than a bourgeois category of essentialised identity.

The second factor in recasting Bildung in a postmodern, postcolonialist frame concerns values. 'Western' values are not universal values but are simply one set of values amongst many others; there is no measure with which to gauge the extent to which they may be any 'better than any others' values; and, in any case, what 'counts' as 'Western' values has always been open to contestation (as much then as now). Gur-Ze'ev (2002, p. 408) makes the postmodern position clear: Bildung cannot deliver truth, 'real' meanings, objective yardsticks or emancipation, but what it can achieve is a 'resistance, refusal, critique and a solidarity that makes a philosophical, existential and political difference'. In a global world increasingly fragmented by economic and social polarisations, a postmodernist, postcolonial Bildung might be enacted as a positive force in developing educative practices which begin in the recognition of difference and diversity.

The third factor central to a postmodernist, postcolonialist stance on Bildung concerns the need to pay closer attention to how values are interlaced with power, and how forms of power/knowledge produce the educative discourses through which we experience education and inhabit its processes. Foucault (1980) talked about the conditions of sayability and visibility which enable discourses to become 'productive' in defining, regulating and legitimating certain 'regimes of truth' for knowing, being and doing in higher education. Thinking Bildung, then, as a discursive practice for regulating what counts as a 'valid' educational experience (and what doesn't count or is 'invalid'), in which particular forms of knowledge (and not others) are validated and certified, and for regulating particular educational identities as legitimate (for example being a 'good' student) while disavowing 
others, has led some postmodernist, postcolonial thinkers to see classical notions of Bildung as an exemplary expressions of how 'power defines what gets to count as knowledge' to borrow Flyvbjerg's (2001, p. 155) phrase. This is particularly evident in its valorisation of a liberal arts curriculum as a hallmark of 'reason' and 'civilisation', and in the dominant codes of Western science education which assume a dualist ontology, and an 'objective' epistemological stance as the guarantor of Truth. But, as Biesta (2002a, p. 347) points out, 'we must at least acknowledge that what is called the rational life is itself but one tradition'. Postmodernist, postcolonial notions of Bildung, in drawing attention to how knowledge is bound up with gendered (and 'classed', 'raced', heteronormative, and 'ableist') power relations, urge us to install a more multifarious view of knowledge and more heterogeneous ways of knowing in higher education. One particularly good example of this is Cajete's (1994) project of decolonising science education which embraces the knowledge-making practices of Indigenous people. Such a postmodern, postcolonial reconstruction of Bildung as a politics of location promises a higher education that is about much more than the transmission of facts to the next generation.

\section{A canine Bildung}

Gustavsson's (2004, p. 109) view that 'Bildung is a contested concept; different parts of it are used for the purpose at hand' is worth bearing in mind with regard to a recent use of it which elaborates a canine Bildung. Kendall-Morwick (2014) appropriates and reshapes Bildung via a reading of Virginia Woolf's novel Flush which relates the biography of its eponymous hero, a spaniel who lives first with his mistress in London, then travels to Florence with her. Flush has a penchant for the Greek lexicon and for listening to the harp. Flush is Elizabeth Barrett Browning's dog and Flush's story is entwined with the story of her romance and marriage to Robert Browning. Kendall-Morwick reads Flush as a canine Bildungsroman in which the Bildung processes of Flush parallel those of the woman poet, tracing how both are conditioned by patriarchal, sexist and humanist assumptions about identity. Kendall-Morwick's (2014) central argument is that Bildung provides a useful way of reflecting on how human-animal entanglements help to shape human experiences, and provoke a rethinking of the boundaries between them that have held the category of the human so firmly in place for so long. Kendall-Morwick points out that constructing the category of the human has been central to the educative enterprise of Bildung, and is in agreement with Biesta that Bildung is not 'something universal, external or "typically human"' but is subject to continuing re/construction and articulation in order to distinguish the category of 'human'—or some humans-from inferior others (Biesta 2002a, p. 346).

In addition to the questions, it raises of what constitutes the category of 'human', a canine Bildung brings into much sharper focus broader issues concerning subjectivity and creativity, learning and knowing, as recent work by scholars in the interdisciplinary field of animal studies indicates. Massumi (2014), for example, proposes that when animals and humans play together, they are caught up in non-individual forces that traverse and exceed their discrete bodies and that far from creativity being an originary human trait, animal biology reveals animals as playfully inventive, experimental and creative, while Willett's (2014) findings suggest that animals' play and laughter is oriented to the cooperative establishment of animal-human communities based on a 'biosocial' conception of self. These studies undermine cognitivist, individualised notions of learning, knowing and selfformation, and give a taste of how current debates in animal studies might inform a reconceptualisation of Bildung. And while the radical ways of thinking about self and subjectivity proposed by animal studies are currently at odds with a higher education 
system largely oriented to human employability, economic efficiency, individual performativity and institutional competition, nevertheless such thinking is valuable. It provides a glimmer of a different articulation of Bildung and, therefore, of a different educative project for higher education, and lends support to my question: is a posthuman Bildung possible?

The remainder of the article addresses this question. Like the three lenses above, a posthumanist Bildung offers a radical reformulation which contests some of the central presuppositions of 'classical' Bildung's while retaining its allegiance to educative practices that are more than technical, instrumental or input-output.

\section{Posthumanism and educative practices}

It is probably worth beginning with a brief résumé of the central tenets that underpin posthumanist ways of thinking. Posthumanism, like Bildung, is a mobile category and one that is taken up in a variety of different ways by different theorists. It is a resolutely inter-, or postdisciplinary constellation of different theories, approaches, concepts and practices. As I note elsewhere:

It includes (in no particular order): animal studies; 'new' material feminism; affect theory; process philosophy; assemblage theory; queer theory; speculative realism; thing theory; actor network theory; the nonhuman; the new empiricism; posthuman disability studies; object-oriented ontology, alien phenomenology, ecological relationality, decolonial and indigenous theories, plus others I don't know about (Taylor 2016).

While it is undoubtedly an emerging field in theoretical flux, posthumanist thought coheres around one central presumption. That is: posthumanist thinkers begin by questioning the human as a privileged category. They argue that the binary that Humanism instituted and which has been used to mark the human off as a separate, exceptional, distinct, privileged and 'superior' category of being than the rest of life in the universe is illegitimate and fallacious. Undoing the privileged category of 'the human' throws into doubt much of the Enlightenment edifice that sustained the genealogy of 'Man'. Thus, posthumanism seeks to undermine the boundaries that have been put into place with regard to theory and practice, mind and body, brain and body, self and other, reason and emotion, human and nature, human and animal, male and female. The ontological, epistemological and ethical recasting that ensues, and which I trace the implications of below in relation to a posthumanist Bildung, is profound, but it will be clear already that posthumanism proposes very different starting points for educational research, the production of knowledge about education, and how to grasp educational experience than that disclosed by Humanism.

Posthumanist responses to how to deal with the legacies and effects of Humanism in order to conceptualise posthumanism are various, and Braidotti's (2013) points that any desire to 'overcome humanism' quickly brings us face to face with our entanglement with it, rings true. This is perhaps particularly so with the project of higher education which exemplifies commitments to progress, to developments which sustain and enhance us, and social justice for a better (and more inclusive) future. These are also all things that a posthumanist Bildung would wish to continue to adhere to. In my view, a posthumanist reconfiguration of Bildung pluralises the conceptualisation of educative practices so to take 
into account the bodies, things, spaces and materialities alongside and with the human. This is an urgent task in education today, given that more and more of what and how we learn happens in and through our dependence on virtual, physical and material artefacts as much as through human instructional frames. It is also urgent because it makes us pay attention to the fact that all learning is spatially located-it happens somewhere-and that that somewhere is an intimate if unspoken and unacknowledged part of our bodily experience of education. The more-than-human and non-human entities (things, objects, materialities, spaces) of education are, when considered in a posthuman frame, given the respect they deserve and require as actors in their own right. Posthumanism, then, provides a way of thinking of educative practices beyond the limits of cognitive effects, intellectual input and output of 'content', and the effects of human behaviour. It re-situates them in relation with the nonhuman and more-than-human aspects of the world that surround us and with which (or whom) we interact as learning happens.

In taking this line, I am drawing on the theories of Karen Barad (2007) and Jane Bennett (2010), in particular, who propose that human-nonhuman relations exist through ecologies of co-emergence in which we (all) are embedded and entangled and within which the human is only one of the many agencies, all of whom together contribute to whatever it is that is educative about any particular experience. This stance helps give matter its due (a matter which is long overdue in education) and draws attention to the issue of 'responseability - the ability to respond [as a] particular practice [...] of engagement' (Kleinmann and Barad 2012, p. 81). Furthermore, it helps to both pluralise and specify educative practices as materially co-constitutive doings and actions. Thus, I do not propose a 'throw the baby out with the bathwater' approach. Rather, a posthuman Bildung needs to remain attentive both to 'what works' and what might be made better as long as this includes humans, nonhumans and other-than-humans alike. I argue below that taking such posthuman entanglements seriously requires an ethical re-casting of Bildung in ways which sharpen debates about the (Humanist) projects of social justice and citizenship. Before that, I explore what a posthumanist Bildung does to ontology and epistemology. I engage Barad's (2007) agential realism to frame a posthumanist Bildung which coheres around the concept of ethico-onto-epistemology. I argue against the separation of the mind and body and propose, instead, a form of knowing-in-being in which learning as a materially embodied and emplaced sensory knowing enables us to ask new and different questions about ways of being, knowing and doing, such that a posthuman Bildung becomes a possibility.

\section{Towards a posthuman Bildung: rethinking ontology}

A posthumanist education is about seeking ways to engage 'a future politics not reducible to anthropocentric institutions and practices' (Snaza 2015, p. 27) which means that a posthuman Bildung begins in different ontological presumptions about the modes of being through which humans and nonhumans inhabit the world than that proposed by existing modes of Bildung. von Humboldt (1969, p. 58) wrote:

It is the ultimate task of our existence to achieve as much substance as possible for the concept of humanity in our person, both during the span of our life and beyond it, through the traces we leave by means of our vital activity. This can be fulfilled only by the linking of the self to the world to achieve the most general, most animated, and most unrestrained interplay. 
To adapt von Humboldt, a posthuman Bildung would be about realising as much substance for the 'unrestrained interplay' of 'vital activity' between ourselves and the morethan-human others with whom we share the world. Karen Barad's (2007) concepts of intraaction and entanglement provide useful starting points to theorise and activate such a posthuman Bildung. Barad (2007) challenges the assumed separability of self, object and world. She argues that objects and subjects do not exist before or outside intra-actions but come into being as subjects and objects through intra-actions. In simple terms, nothing exists in and of itself; everything comes into being through intra-active relations. Barad draws on quantum physics to explain this: in nature nothing is separate, everything is codetermined and entangled in a mutually constitutive ecology of relations, and all things exist in an ongoing dynamism of mattering. Humans are the one who, for their analytic convenience and to establish a mode of supremacy, have instituted boundaries and thereby produced objects and subjects. These boundaries and separations are produced through what Barad calls an 'agential cut' (ibid, p. 140) but, crucially, such cuts enact boundaries within entanglement, for any 'cut' remains part of the phenomena produced. Intra-actions are material-discursive practices: they have effects that matter.

Agential realism has significant implications for ontology. Agency is not an attribute of a person, it is not located in individual human bodies, and it is not an expression of 'free will'. Agency is an ongoing becoming and reconfiguring that happens as we (humans) interact with each other and with all the other bodies, agencies, materialities that surround us. In this account, agency is re-thought as an 'ongoing ebb and flow' (ibid, p. 140) in which 'we' and 'I' come into being through specific intra-actions in open-ended practices. As Barad (2007, p. 139) explicitly states: 'the primary ontological unit is not independent objects with inherent boundaries and properties but rather phenomena', whereby 'phenomena are the ontological inseparability/ entanglement of intra-acting agencies'. Agential realism rethinks ontology as a confederacy of agencies acting in concert in horizontal relations; it proposes a flattened ontology in place of the hierarchical ontology of Humanism. Such a recasting of ontology has three significant implications for the development of a posthuman Bildung. One, it reworks the individual's process of selfdevelopment, unfolding, and self-cultivation not as an inner, private or purely individual experience but as a dynamic enactment or practice that happens intra-actively, because 'subjects [are] intra-actively co-constituted through the material-discursive practices that they engage in' (ibid, p. 168). Two, it enables a larger space for taking the dynamism of matter into account. A posthuman Bildung would be responsive to the fact that 'matter is produced and productive, generated and generative. Matter is agentive, [it is] not a fixed essence or property of things' (ibid, p. 137). And three, the traditional notion that Bildung proceeds according to an organic concept of nature and natural development is also somewhat recast. In a posthuman frame, nature and culture are not conceived as separate entities, nor does 'culture' work on 'nature' to transform or appropriate it for (human) ends and purposes. Rather, all processes are 'naturalcultural' practices, an intermingling and mixture of different forms and modes of materiality, and their binary separation (nature/ culture) is yet another human-centric 'practice of mattering through which intelligibility and materiality are constituted' (Barad 2007, p. 170).

In pursuing this line, then, Barad's recasting of ontology as an intra-active doing rather than an individual property or human attribute contests the fundamental presumptions of a (Humanist) Bildung. While a Humanist Bildung is about 'the self-forming of the soul' and sees the inner as 'always the immaterial, [because] only in this way a connection can be 
made with the ideas of the good, true and beautiful' (Oelkers 1999, pp. 29-30), a posthumanist Bildung presupposes ontology as intra-active, confederate, democratic, material and engaged, and pushes the reconceptualisation of educative practices towards process-based material matterings in which humans figure as one agency in a distributed assemblage of agencies. In terms of higher education pedagogies, to give one practical example, this might entail paying more attention to the material force of learning outcomes which, as encoded in course documentation and module handbooks (or, more widely, in the panoply of university documentation that defines and regulates 'quality assurance' or 'teaching excellence' or 'student engagement'). Such documents act as material agents in constituting the types of learning that occur, the kinds of knowledge generated, the spatiomateriality of the pedagogic relations that take place and, therefore, the bodily modes of being and becoming that are made possible. A posthuman higher education pedagogy, in which learning outcomes are recognised as material matterings in the world, issues an invitation to be more curious about our more-than-human entanglements, and displaces didactic transmission in favour of pedagogy as emergent orchestration of heterogeneous elements (Gough 2004). A posthuman Bildung, therefore, is activated in awareness that any individual's (self-)shaping only occurs in intra-active processes with many different 'others' in a shifting and processual assemblage of co-constitutive events, instances and process. More than that, a posthuman pedagogy works beyond familiar divisions between process and content, theory and practice, the personal and the professional which currently mark higher education teaching and learning, and draws into its orbit those things that might ordinarily be designated as being 'outside' the pedagogic relation (debt, work, family, memories, affects). A posthuman Bildung is an immanent experiment in connection.

\section{Towards a posthuman Bildung: rethinking epistemology}

Just as there is no ontological separation between inner/outer, mind/body, self/nature, a posthuman epistemology proposes that knowledge is not a 'body of concepts or theories' separate from the knower, but is entangled with/in them. The various splits that follow from Descartes cogitio - that is, the split between brain/body, reason/ emotion, cognitive/ affective, intellectual/sensation—are, Barad proposes, false separations. For Barad, knowledge practices are material enactments: learning, teaching and assessment are material-discursive practices, doing and actions that co-constitute the curriculum and what counts as knowledge. As she says:

Making knowledge is not simply about making facts but about making worlds, or rather it is about making specific worldly configurations - not in the sense of making them ex nihilo, or out of language, beliefs, or ideas, but in the sense of materially engaging as part of the world in giving it specific material form. (Barad 2007, p. 91)

I have discussed elsewhere that in a posthuman agential realism knowledge is emergent and embodied, that knowledge practices are entangled matters of human-nonhuman apparatuses or assemblages, and that it might be better to think, not of the 'production' of knowledge as a finite 'thing', but as an ongoing, intra-active enactment of 'knowledgeing', that is, as an open-ended process in which sense, intuition and those 'eureka moments' feature alongside and as strongly as logic, deduction and rationality (Taylor 2013). Such understandings take forward sociology of knowledge approaches and, as 
intimated earlier, undoing a Humanist, progressivist Bildung which polices what 'counts' as valuable knowledge means including indigenous, feminist, postcolonialist and posthumanist forms of knowledge-making in order to go beyond 'local' epistemologies, anthropocentrism and speciesism.

However, thinking a posthuman higher education curriculum in which a plurality of epistemologies may flourish offers a fundamental challenge to the edifice of subjects and disciplines that have for so long been the building blocks and containing boxes for knowledge. However, significant shifts in this direction have already occurred. The separate tribes and territories identified as conditioning disciplinary ways of knowing and academic identities have now morphed into much more fluid arrangements which speak to the contestation and contextual contingency of disciplinary boundaries and practices (Trowler et al. 2014). There is also evidence to indicate that cutting-edge knowledgemaking in fields as diverse as neuroscience, cultural geography and new materials manufacturing is increasingly occurring in the interdisciplinary interstices, in order that the differentiated and specialised knowledge of 'different' disciplines can be harnessed to throw light on increasingly complex and unwieldy problems. Posthuman curricula push interdisciplinary trends further, reorienting learning towards think beyond anthropocentrism and speciesism, making postdisciplinarity a curriculum resource and a posthuman Bildung a mode of entangled knowing-in-being that undoes linearity, highlights knowledge as a messy multiplicity, and privileges the affective as much as the cognitive. Knowledge and knowing become an entirely different matter: 'truth' is not generalisable and there is no 'outside' place from which to obtain an objective view of things. Instead, local and situated knowledges work to support a new, ecological relation between the general and the particular, in ways which validate heterogeneous knowledge pathways, and intersect with non-foundational, non-canonical works.

The contestability and instability of knowledge requires replacing Bildung as a linear, teleological project with a more humble notion of Bildung as an erratic, recursive and meandering which is, nevertheless, a going somewhere. Biesta (2002a, p. 348) puts forward that argument that 'the modern conception of Bildung as "rational liberation" is no longer possible in a world in which we take difference seriously'. So it may be that figuring Bildung as a posthuman going somewhere, a wandering-with and in relation to, othershuman and other-than-human-rather than an inward, individual or spiritual journey offers a better fit with the increasingly hybrid ways of knowledge-making in a contemporary world of migrant flows, global dislocations and ecological upheavals.

\section{Towards a posthuman Bildung: rethinking ethics}

A posthumanist ethics begins with relationality. The human is conceived in relation to the nonhuman, and both are of equal value in a horizontal ontology. Including the nonhuman in questions about who matters and what counts, I suggest, opens up a new ethics of engagement for education. Biesta's (2002a, p. 349) view is that any contemporary versions of Bildung worth their salt needed to recognise our interdependence, arguing that the 'task - a future task, a future-for Bildung here ... might be to help to create an awareness, or better, perhaps, an experience that the only way in which we can live our lives is with others'. This statement usefully directs us to the origins of the tradition of Bildung in which 'cultivation' entails social, political and ethical dimensions which shape an individual's pathway not just as an individual but as a citizen in the social world. The 'citizenship 
project' that Bildung articulates has always been about more than a juridical relation between the individual and the state, just as it has always figured citizenship as more than an achieved status expressive of an essentialised state of being. Indeed, Bildung has always spoken to a wider view of citizenship in which democratic impulses are articulated in values, dispositions, ways of being and concrete practices (Lawy and Biesta 2006; Olson et al. 2015). A posthuman Bildung resonates with and complicates this view. It adds to it by pluralising what and who counts as those 'others' with whom we (humans) live our lives, thus erasing the differences that Humanism installed at the heart of relations. It replaces difference as alterity with different with/in entanglement, thereby reconstituting Bildung as a postanthropocentric ethic of encounter which moves beyond speciesism and hierarchy towards modes of interbeing, interspeciesbeing and worlding (Taylor 2016). These new modes of contact generate new responsibilities, accountabilities and commitments, which emerge in the embodied specificity of incarnate relations, not in universalist codes. As Bennett (2010, p. 37) notes: 'the ethical responsibility of an individual human now resides in one's response to the assemblages in which one finds oneself participating'.

Such a view of ethics-in-relation does not sit well with the traditional assumption that Bildung happens within the 'Bildungssystem', that is, within the walls of the educational system as it is institutionalised in schools, colleges and universities. However, it does resonate with the idea of the 'ecological university' which focuses on well-being, care and interconnectedness. However, while Barnett's ecological university is formulated in anthropocentric terms as 'a metaphor for the fullest expression of possibilities for this earth and for the place of humanity on it' (Barnett 2011, p. 142), I want to suggest an idea of the university as an entangled posthuman partnership in world-making. Such an ethical posthuman formulation replaces notions of care for the 'world' as a separate other available to 'us' (humans) for 'our' benefit with an embodied practice of accountability which registers a continual awareness of our relational becoming-with human and nonhuman others with whom we share this world. A posthuman Bildung is a lifelong task of realising one's responsibility within an ecology of world relations, it occurs outside as well as inside formal education, in virtual as well as 'real' places. Furthermore, a posthuman Bildung interrogates what 'citizenship' as a political project might mean, it deepens and extends ethical accountably by reformulating who and what social justice is 'for' and includes, and complicates all such projects by positing that all our educative encounters are material, coemergent and experimental becomings which cannot be planned or known in advance. Biesta (2002a, p. 350) nicely captures the promise of Bildung as 'an image of a learning society ... in which the real encounters with who and what is other are a constant and continuous possibility'. This, I would suggest, is a posthuman Bildung worth struggling for, and one that requires higher education to develop posthuman pedagogies and curricula to enable and support it.

\section{Conclusion: the promise of a posthumanist Bildung}

In this article, I have suggested that we need to take the temperature of Bildung to see whether its promise can be reconstructed in a posthumanist frame. I have argued that such an endeavour is worthwhile because, in its allegiance to education as an expressive mode of being, becoming and belonging, Bildung speaks to a wider sensibility regarding the transformative potential of education. If, historically, Bildung was an educational response to a political question (about the individual in civil society), then the task right now is to 
ask: 'what kind of Bildung might be needed or might make sense for us here and todayand what kind of Bildung might be possible' (Biesta 2002a, p. 346). My response to this question is to propose the need for a posthumanist Bildung. This is because we are already living in posthuman times, where gene therapy, three person embryos, drones, technological innovations, GM foods, global warming, mass refugee migrations, continual warfare and the extinction of many species have thrown the nature of the 'human', the boundaries of the 'human' and the progressivist mission of Humanism into doubt. Education is no longer a purely human affair; education is a matter of intra-active entanglements that enfold 'us' all, human and other-than-human alike, in the world's dynamic and emergent mattering. Barad (2007, p. 170) says that "bodies do not simply take their place in the world ... rather "environments" and "bodies" are intra- actively constituted' which is why I think arguments for a posthuman Bildung are worth pursuing. Rethinking Bildung in a posthuman educational frame is about rethinking agency beyond the individual, such that agency is enlarged, shared and confederate; it is about recognising the human as a dynamic naturalcultural enactment, not as a means for (some) humans to achieve dominion over nonhumans and human 'others'; and it is about doing away with those binaries that presume separation between inner/outer, thought/action, personal/professional and content/process. A posthuman Bildung is a matter of spirituality and materiality which means that it is not an 'inner process' but a educative practice oriented to making a material difference in the world. A posthuman Bildung is, therefore, nothing more or less than education as an ethico-onto-epistemological quest for (better ways of) knowing-in-becoming.

Acknowledgments Thank you to the two anonymous reviewers and the editor who engaged with my ideas so thoughtfully. Your comments undoubtedly helped me improve the paper.

Open Access This article is distributed under the terms of the Creative Commons Attribution 4.0 International License (http://creativecommons.org/licenses/by/4.0/), which permits unrestricted use, distribution, and reproduction in any medium, provided you give appropriate credit to the original author(s) and the source, provide a link to the Creative Commons license, and indicate if changes were made.

\section{References}

Barad, K. (2007). Meeting the universe halfway - quantum physics and the entanglement of matter and meaning. Durham: Duke University Press.

Barnes, C., \& Jenkins, C. (2014). Student satisfaction negates pedagogic rights, theirs and ours! Student Engagement and Experience Journal. Accessed online 12 Aug 2015, http://research.shu.ac.uk/SEEJ/ index.php/seej/article/view/97

Barnett, R. (2011). Being a university. London: Routledge.

Barnett, R. (2013). Relating the ineffable: Recovering the universal student in a marketised age. Keynote presentation at The ethics of student engagement symposium, University of Brighton, 4 July 2013.

Bennett, J. (2010). Vibrant matter: A political ecology of things. London: Duke University Press.

Biesta, G. (2002a). Bildung and modernity: The future of Bildung in a world of difference. Studies in Philosophy and Education, 21, 343-351.

Biesta, G. (2002b). How general can Bildung be? Reflections on the future of a modern educational ideal. Journal of Philosophy of Education., 36(3), 377-390.

Bovill, C., Cook-Sather, A., \& Felten, P. (2011). Students as co-creators of teaching approaches, course design, and curricula: Implications for academic developers. International Journal for Academic Development., 16(2), 133-145.

Braidotti, R. (2013). The posthuman. Cambridge: Polity.

Buckley, A. (2014). UK engagement survey 2014: The second pilot year. York: HEA. 
Business, Innovation and Skills Department. (2015). Fulfilling our potential: Teaching excellence, social mobility and student choice. London: Crown Copyright.

Cajete, G. (1994). Look to the mountain: An ecology of indigenous education. Durango, CO: Kikavi Press.

Castle, G. (2013). My self, my other: Modernism and postcolonial Bildung in Assia Djebar's Algeria Quartet. Modern Fiction Studies., 59(3), 629-648.

Collini, S. (2012). What are universities for?. London: Penguin.

Dall'Alba, G., \& Barnacle, R. (2007). An ontological turn for higher education. Studies in Higher Education, 32(6), 679-691.

Deleuze, G., \& Guattari, F. (1994). What is philosophy? Translated by Graham Burchell and Hugh Tomlinson. London: Verso.

Dohmen, G. (1964). Bildung und Schule. Die Entstehung des deutschen Bildungsbe- griffs und die Entwicklung seines Verhältnisses zur Schule. Bd. 1: Der religiöse und der organologische Bildungsbegriff. Weinheim: Beltz.

Flyvbjerg, B. (2001). Making social science matter. Cambridge: Cambridge University Press.

Foucault, M. (1980). Power/knowledge: Selected interviews and otherwWritings 1972-1977. New York: Harvester Wheatsheaf.

Giesinger, J. (2012). Liberal education/Bildung: Arguments for and against. Seminar at the Katholieke Universiteit Leuven, October 17th, 2012.

Gough, G. (2004). RhizomANTically becoming-cyborg: Performing posthuman pedagogies. Educational Philosophy and Theory., 36(3), 253-265.

Gur-Ze'ev, I. (2002). Bildung and critical theory in the face of postmodern education. Journal of Philosophy of Education, 36(3), 392-408.

Gustavsson, B. (2004). Bildung and the road from a classical into a global and postcolonial concept. Confero, 2(1), 109-131.

Healey, M., Flint, A., \& Harrington, K. (2014). Engagement through partnership: Students as partners in learning and teaching in higher education. York: Higher Education Academy.

HEFCE. (2015). New approach to ensure high-quality learning and teaching in universities and colleges. http://www.hefce.ac.uk/news/newsarchive/2015/Name,104412,en.html. Accessed 18 Aug 2015.

Herder, J. G. (1769/1992). In K. Mommsen (Ed.), Journal meiner Reise im Jahr 1769. Stuttgart: Reclam.

HESA (2015). UK Performance Indicators. https://www.hesa.ac.uk/pis/guide. Accessed 20 Aug 2015.

Horlacher, R. (2004). Bildung-A construction of a history of philosophy of education. Studies in Philosophy and Education, 23, 409-426.

Kendall-Morwick, K. (2014). Mongrel fiction: Canine Bildung and the feminist critique of anthropocentrism in Woolf's Flush. Modern Fiction Studies., 60(3), 506-526.

Kern, H. (2010). Humboldt's educational ideal and modern academic education. Presentation at 26th Annual Meeting of the Danube Rectors Conference, 04-06 Feb 2010, Novi Sad, Serbia.

Kleinmann, A., \& Barad, K. (2012). Intra-actions: An interview with Karen Barad. Mousse Magazine, 32, 76-81.

Lawy, R., \& Biesta, G. (2006). Citizenship-as-practice: The educational implications of an inclusive and relational understanding of citizenship. British Journal of Educational Studies., 54(1), 34-50.

Massumi, B. (2014). What animals teach us about politics. London: Duke University Press.

Molesworth, M., Nixon, L., \& Scullion, R. (2011). The marketisation of higher education and the student as consumer. London and New York: Routledge.

Neary, M. (2010). Student as producer: a pedagogy for the avant-garde? Learning Exchange. 1(1).

Newman, J. H. (1996). The idea of a university. New Haven: Yale University Press.

Oelkers, J. (1999). The origin of the concept of "allgemeinbildung" in 18th century Germany. Studies in Philosophy and Education, 18, 25-41.

Olson, M., Fejes, A., Dahlstedt, M., \& Nicoll, K. (2015). Citizenship discourses: Production and curriculum. British Journal of Sociology of Education, 36(7), 1036-1053.

Ransome, P. (2011). Qualitative pedagogy versus instrumentalism: The antinomies of higher education learning and teaching in the UK. Higher Education Quarterly, 65(2), 206-223.

Ranson, S. (2003). Public accountability in the age of neo-liberal governance. Journal of Education Policy, $18(5), 459-480$.

Sayer, A. (2011). Why things matter to people: Social science, values and ethical life. Cambridge: Cambridge University Press.

Snaza, N. (2015). Toward a genealogy of educational humanism. In N. Snaza \& J. Weaver (Eds.), Posthumanism and educational research. London: Routledge.

Stronach, I., \& MacLure, M. (1997). Educational research undone: The postmodern embrace. Buckingham: Open University Press. 
Taylor, C. A. (2013). Objects, bodies and space: Gender and embodied practices of mattering in the classroom. Gender and Education, 25(6), 688-703.

Taylor, C. A. (2016). Edu-crafting a cacophonous ecology: Posthumanist research practices for education. In C. A. Taylor \& C. Hughes (Eds.), Posthumanist research practices in education. London: Palgrave MacMillan.

Taylor, C., \& McCaig, C. (2014). Evaluating the impact of number controls, choice and competition: An analysis of the student profile and the student learning environment in the new higher education landscape. York: Higher Education Academy.

Thavenius, J. (1995). Den motsägesfulla bildningen. Stockholm: Stehag.

Trowler, P., Saunders, M., \& Bamber, V. (Eds.). (2014). Tribes and territories in the 21st century. London: Routledge.

von Humboldt, W. (1969). Theorie der Bildung des menschen. In A. Flitner \& G. Klaus Giel (Eds.), Wilhelm von Humbodt, Werke in fiinf Biinden: Vol. I. Schriften zur Anthropologie und Geschichte. Darmstadt: Wissenschaftliche Buchgesellschaft.

Willett, C. (2014). Interspecies ethics. New York: Columbia University Press. 